\title{
Caenispirillum bisanense gen. nov., sp. nov., isolated from sludge of a dye works
}

Correspondence

Jung-Hoon Yoon

jhyoon@kribb.re.kr

\author{
Jung-Hoon Yoon, So-Jung Kang, Sooyeon Park and Tae-Kwang Oh \\ Korea Research Institute of Bioscience and Biotechnology (KRIBB), PO Box 115, Yusong, \\ Taejon, Korea
}

\begin{abstract}
Two Gram-negative, non-spore-forming, motile and helical-shaped bacterial strains, $\mathrm{K} 92^{\top}$ and $\mathrm{K} 93$, were isolated from sludge from a dye works in Korea, and their taxonomic positions were investigated by means of a polyphasic approach. Strains $\mathrm{K} 92^{\top}$ and $\mathrm{K} 93$ grew optimally at $37^{\circ} \mathrm{C}$ and $\mathrm{pH} 7.0-8.0$ in the presence of $0.5 \%(\mathrm{w} / \mathrm{v}) \mathrm{NaCl}$. They contained Q-10 as the predominant ubiquinone and $\mathrm{C}_{18: 1} \omega 7 \mathrm{c}$ as the major fatty acid. The major polar lipids were phosphatidylcholine, phosphatidylglycerol, diphosphatidylglycerol, phosphatidylethanolamine and two unidentified amino-group-containing lipids that were ninhydrin-positive. Their DNA G+C contents were $70.0 \mathrm{~mol} \%$. The $16 \mathrm{~S}$ rRNA gene sequences of $\mathrm{K} 92^{\top}$ and $\mathrm{K} 93$ showed no differences, and the two strains had a mean DNA-DNA relatedness of $93 \%$. Phylogenetic analyses based on $16 \mathrm{~S}$ rRNA gene sequences showed that strains $\mathrm{K} 92^{\top}$ and $\mathrm{K} 93$ formed a distinct evolutionary lineage within the Alphaproteobacteria. The $16 \mathrm{~S}$ rRNA gene sequences of strains $\mathrm{K}^{2} 2^{\top}$ and $\mathrm{K} 93$ exhibited similarity values of less than $91.5 \%$ with respect to the $16 \mathrm{~S}$ rRNA gene sequences of other members of the Alphaproteobacteria. The two strains were distinguishable from phylogenetically related genera through differences in several phenotypic properties. On the basis of the phenotypic, phylogenetic and genetic data, strains $\mathrm{K}_{2}{ }^{\top}$ and $\mathrm{K} 93$ represent a novel genus and species, for which the name Caenispirillum bisanense gen. nov., sp. nov. is proposed. The type strain of Caenispirillum bisanense is $\mathrm{K}^{\top} 2^{\top}\left(=\mathrm{KCTC} 12839^{\top}=\mathrm{JCM} 14346^{\top}\right)$.
\end{abstract}

In an attempt to investigate the microbial community in sludge from the wastewater treatment plant of a dye works in Korea, many bacterial strains were isolated and characterized taxonomically. This study focuses on two of these isolates, designated strains $\mathrm{K} 92^{\mathrm{T}}$ and $\mathrm{K} 93$. Comparative $16 \mathrm{~S}$ rRNA gene sequence analysis indicated that strains $\mathrm{K}^{2} 2^{\mathrm{T}}$ and K93 form a deep branch within the Alphaproteobacteria. Accordingly, the aim of the present work was to determine the exact taxonomic positions of strains $\mathrm{K}^{\mathrm{T}}{ }^{\mathrm{T}}$ and $\mathrm{K} 93$ by using a polyphasic characterization that included the determination of phenotypic properties, a detailed phylogenetic analysis based on 16S rRNA gene sequences and analysis of genetic relatedness data.

A sludge sample collected from the wastewater treatment plant of a dye works at Daegu, Korea, was used as the source for the isolation of bacterial strains. Strains $\mathrm{K} 92^{\mathrm{T}}$ and $\mathrm{K} 93$ were isolated on nutrient agar (Difco) and trypticase soy

\footnotetext{
The GenBank/EMBL/DDBJ accession numbers for the 16S rRNA gene sequences of strains $\mathrm{K} 92^{\top}$ and $\mathrm{K} 93$ are respectively EF100694 and EF100695.

A transmission electron micrograph of a cell of strain $\mathrm{K} 2^{\top}$ and cellular fatty acid profiles of strains $\mathrm{K} 92^{\top}$ and $\mathrm{K} 93$ and related taxa are available as supplementary material with the online version of this paper.
}

agar (TSA; Difco) at $30^{\circ} \mathrm{C}$, using the standard dilution plating technique. Aquaspirillum itersonii subsp. itersonii LMG $4337^{\mathrm{T}}$, Aquaspirillum itersonii subsp. nipponicum LMG $7370^{\mathrm{T}}$, Aquaspirillum peregrinum subsp. peregrinum LMG $4340^{\mathrm{T}}$ and Aquaspirillum peregrinum subsp. integrum LMG $5407^{\mathrm{T}}$ were obtained from the Laboratorium voor Microbiologie Universiteit Gent (LMG), Ghent, Belgium. The morphological, physiological and biochemical characteristics of strains $\mathrm{K} 92^{\mathrm{T}}$ and $\mathrm{K} 93$ were investigated using routine cultivation on TSA at $37^{\circ} \mathrm{C}$. Cell morphology was examined by light microscopy (E600; Nikon) and transmission electron microscopy. Flagellation was determined by using a Philips CM-20 transmission electron microscope with cells from exponentially growing cultures: for this purpose, the cells were negatively stained with $1 \%(\mathrm{w} / \mathrm{v})$ phosphotungstic acid and the grids were examined after being air-dried. The Gram reaction was determined by using the bioMérieux Gram stain kit according to the manufacturer's instructions. Growth at various temperatures $\left(4-50{ }^{\circ} \mathrm{C}\right)$ was measured on TSA. Growth in the absence of $\mathrm{NaCl}$ and at various $\mathrm{NaCl}$ concentrations $(0.5$ and $1.0-10.0 \%, \mathrm{w} / \mathrm{v}$, in increments of $1.0 \%$ ) was investigated in trypticase soy broth prepared according to the formula of the Difco medium except that no $\mathrm{NaCl}$ was used. The $\mathrm{pH}$ range for growth was determined in nutrient broth (Difco) that had been adjusted to various $\mathrm{pH}$ values $(\mathrm{pH} 4.5-10.5$ in 
increments of $0.5 \mathrm{pH}$ units) prior to sterilization by the addition of $\mathrm{HCl}$ or $\mathrm{Na}_{2} \mathrm{CO}_{3}$. Growth under anaerobic conditions was determined after incubation in an anaerobic chamber on TSA and on TSA supplemented with nitrate, both of which had been prepared anaerobically using nitrogen. Catalase and oxidase activities and hydrolysis of casein, gelatin, hypoxanthine, starch, Tweens 20, 40, 60 and 80, tyrosine, urea and xanthine were determined as described by Cowan \& Steel (1965). DNase activity was examined by using DNase test agar with methyl green (Difco). Aesculin hydrolysis and nitrate reduction were studied as described previously (Lanyi, 1987). For in vivo pigment-absorption spectrum analysis, the two novel strains were cultivated aerobically in the dark at $37^{\circ} \mathrm{C}$ in liquid Erythromicrobium/Roseococcus medium (Yurkov et al., 1994; DSMZ medium no. 767) with the modification that trisodium citrate was used instead of acetate. The cultures were washed twice, by centrifugation, using a MOPS buffer (MOPS/NaOH, $0.01 \mathrm{M}$; KCl, $0.1 \mathrm{M} ; \mathrm{MgCl}_{2}, 0.001 \mathrm{M}$; $\mathrm{pH}$ 7.5) and disrupted by sonication with a Branson 450 sonicator. After removal of the cell debris by centrifugation, the absorption spectrum of the supernatant was examined in a Beckman Coulter DU800 spectrophotometer. Antibiotic susceptibility was tested on TSA plates by using antibiotic discs containing the following concentrations: polymyxin B, $100 \mathrm{U}$; streptomycin, $50 \mu \mathrm{g}$; penicillin G, $20 \mathrm{U}$; chloramphenicol, $100 \mu \mathrm{g}$; ampicillin, $10 \mu \mathrm{g}$; cephalothin, $30 \mu \mathrm{g}$; gentamicin, $30 \mu \mathrm{g}$; novobiocin, $5 \mu \mathrm{g}$; tetracycline, $30 \mu \mathrm{g}$; kanamycin, $30 \mu \mathrm{g}$; lincomycin, $15 \mu \mathrm{g}$; oleandomycin, $15 \mu \mathrm{g}$; neomycin, $30 \mu \mathrm{g}$; and carbenicillin, $100 \mu \mathrm{g}$. The utilization of various substrates, activities of various enzymes and other physiological and biochemical properties were tested by using the API 20E, API 20NE, API $50 \mathrm{CH}$ and API ZYM systems (bioMérieux); the cells were suspended in AUX medium, according to the manufacturer's instructions, to inoculate the API $50 \mathrm{CH}$ system.

Cell biomass for DNA extraction and for isoprenoid quinone and polar lipid analyses was obtained from cultivation in trypticase soy broth at $37^{\circ} \mathrm{C}$. Chromosomal DNA was isolated and purified according to the method described by Yoon et al. (1996), with the exception that RNase T1 was used in combination with RNase A to minimize contamination with RNA. The $16 \mathrm{~S}$ rRNA gene was amplified by a PCR using two universal primers, as described previously (Yoon $e t$ al., 1998). Sequencing of the amplified 16S rRNA gene and phylogenetic analysis were performed as described by Yoon et al. (2003). Isoprenoid quinones were extracted according to the method of Komagata \& Suzuki (1987) and analysed using reversed-phase HPLC and a YMC ODS-A $(250 \times 4.6 \mathrm{~mm})$ column. For fatty acid methyl ester analysis, cell mass of strains $\mathrm{K}^{2} 2^{\mathrm{T}}$ and $\mathrm{K} 93$ was harvested from TSA plates after incubation for 2 days at $37^{\circ} \mathrm{C}$, and cell mass of the four Aquaspirillum reference strains was harvested after incubation for 3 days at $28^{\circ} \mathrm{C}$ on solid medium (LMG medium no. 8) that contained $\left(1^{-1}\right.$ distilled water $) 1 \mathrm{~g}$ succinic acid, $10 \mathrm{~g}$ peptone, $1 \mathrm{~g} \quad\left(\mathrm{NH}_{4}\right)_{2} \mathrm{SO}_{4}, 1 \mathrm{~g}$ $\mathrm{MgSO}_{4} \cdot 7 \mathrm{H}_{2} \mathrm{O}, 2 \mathrm{mg} \mathrm{FeCl} 3.6 \mathrm{H}_{2} \mathrm{O}, 2 \mathrm{mg} \mathrm{MnSO}_{4} \cdot \mathrm{H}_{2} \mathrm{O}$ and
$15 \mathrm{~g}$ agar ( $\mathrm{pH} 7.0$ ). The fatty acid methyl esters were extracted and prepared according to the standard protocol of the MIDI/Hewlett Packard Microbial Identification System (Sasser, 1990). The polar lipids were extracted according to the procedures described by Minnikin et al. (1984) and were identified by two-dimensional TLC followed by spraying with the appropriate detection reagents (Minnikin et al., 1984; Komagata \& Suzuki, 1987). The presence of phosphatidylcholine was identified by spraying with Dragendorff reagent (Sigma). The DNA G + C content was determined using the method of Tamaoka \& Komagata (1984), with the modification that the DNA was hydrolysed and the resulting nucleotides analysed by reversed-phase HPLC. DNA-DNA hybridization was performed fluorometrically by using the method of Ezaki et al. (1989) with photobiotin-labelled DNA probes and microdilution wells. Hybridization was performed with five replications for each sample. The highest and lowest values obtained for each sample were excluded and the means of the remaining three values are quoted as DNA-DNA relatedness values.

Morphological, cultural, physiological and biochemical characteristics of strains $\mathrm{K} 92^{\mathrm{T}}$ and $\mathrm{K} 93$ are given in the genus and species descriptions (see below), in Table 1 and in Supplementary Fig. S1 (available in IJSEM Online). The two strains were found to be identical in all of the morphological, cultural, physiological and biochemical characteristics tested in this study, except with regard to susceptibility to polymyxin B. Strains $\mathrm{K} 92^{\mathrm{T}}$ and $\mathrm{K} 93$ did not produce bacteriochlorophyll $a$ aerobically in the dark. Sonicated in vivo cell extracts of the two strains showed an absorption maximum only at $409 \mathrm{~nm}$, which indicated the absence of bacteriochlorophyll $a$ and only the presence of a carotenoid. Extracts obtained using acetone/methanol did not show in vitro maximal absorption peaks. The almost-complete $16 \mathrm{~S}$ rRNA gene sequences of strains $\mathrm{K} 92^{\mathrm{T}}$ and $\mathrm{K} 93$ (comprising $1441 \mathrm{nt}$, representing approximately $96 \%$ of the Escherichia coli $16 \mathrm{~S}$ rRNA sequence) were found to be identical. A comparative 16S rRNA gene sequence analysis showed that strains $\mathrm{K}^{2} 2^{\mathrm{T}}$ and $\mathrm{K} 93$ form a distinct phylogenetic lineage within the Alphaproteobacteria (Fig. 1). In the phylogenetic tree based on the neighbour-joining algorithm, strains $\mathrm{K}^{2}{ }^{\mathrm{T}}$ and K93 joined the phylogenetic clade comprising $A$. itersonii and $A$. peregrinum, with which they exhibited the highest 16S rRNA gene sequence similarity values (91.3-91.5\%). The sequence similarity values with respect to the other species used in the phylogenetic analysis were in the range $81.4-91.2 \%$ (Fig. 1). Strains $\mathrm{K} 92^{\mathrm{T}}$ and $\mathrm{K} 93$ possessed a mean level of DNA-DNA relatedness of $93 \%$ when their DNAs were used individually as labelled DNA probes for cross-hybridization, indicating that the two strains represent the same genomic species (Wayne et al., 1987). In view of the combined phenotypic, phylogenetic and genetic similarities, strains $\mathrm{K} 92^{\mathrm{T}}$ and $\mathrm{K} 93$ could be considered as members of the same species.

The predominant isoprenoid quinone detected in strains K92 ${ }^{\mathrm{T}}$ and K93 was Q-10 (peak area ratio, approx. 94-95\%). 
Table 1. Differential phenotypic characteristics of strains $\mathrm{K} 2^{\top}$ and $\mathrm{K} 93, A$. itersonii and $A$. peregrinum

Taxa: 1, strains $\mathrm{K} 92^{\mathrm{T}}$ and $\mathrm{K} 93 ; 2$, A. itersonii; 3, A. peregrinum. Unless indicated, data for reference taxa were taken from Krieg (1984). +, Positive; -, negative; V, variable. Cells of all taxa are helical in shape, all of the taxa are positive for catalase, oxidase and aesculin hydrolysis and all are negative for Gram-staining, indole production and hydrolysis of casein and gelatin.

\begin{tabular}{|c|c|c|c|}
\hline Characteristic & 1 & 2 & 3 \\
\hline Growth at $3 \%(\mathrm{w} / \mathrm{v}) \mathrm{NaCl}$ & + & - & - \\
\hline Growth on MacConkey agar & + & $+^{*}$ & $-\dagger$ \\
\hline Anaerobic growth with $\mathrm{KNO}_{3}$ & + & + & - \\
\hline Nitrate reduction to nitrite & + & - & - \\
\hline $\mathrm{H}_{2} \mathrm{~S}$ production & - & + & + \\
\hline \multicolumn{4}{|l|}{ Hydrolysis of: } \\
\hline DNA & + & $+^{*}$ & $-\dagger$ \\
\hline Starch & + & - & - \\
\hline Urea & - & - & + \\
\hline $\begin{array}{l}\text { Temperature range for } \\
\text { growth }\left({ }^{\circ} \mathrm{C}\right)\end{array}$ & $15-47$ & $12-42$ & $11-40$ \\
\hline $\mathrm{pH}$ range for growth & $6.5-10.0$ & $5.5-9.0$ & $5.5-9.0$ \\
\hline \multicolumn{4}{|l|}{ Utilization of: $\ddagger$} \\
\hline Adipate & + & - & - \\
\hline Citrate & + & - & - \\
\hline Malate & + & + & - \\
\hline Glycerol & + & $\mathrm{v} \S$ & - \\
\hline Aesculin & - & - & + \\
\hline D-Fructose & - & + & + \\
\hline Ribose & + & - & - \\
\hline Gluconate & + & - & - \\
\hline DNA G $+\mathrm{C}$ content $(\mathrm{mol} \%)$ & 70.0 & $60-66\left(T_{\mathrm{m}}\right)$ & $60-64\left(T_{\mathrm{m}}\right)$ \\
\hline
\end{tabular}

${ }^{\star}$ Not determined for A. itersonii subsp. nipponicum.

$\dagger$ Not determined for A. peregrinum subsp. integrum.

¥Data from this study.

§ositive for $A$. itersonii subsp. nipponicum but negative for $A$. itersonii subsp. itersonii.

Strains $\mathrm{K} 92^{\mathrm{T}}$ and $\mathrm{K} 93$ had cellular fatty acid profiles that contained large amounts of unsaturated, straight-chain and hydroxy fatty acids; the major component was $\mathrm{C}_{18: 1} \omega 7 c$ (see Supplementary Table S1 in IJSEM Online). The major polar lipids detected in strains $\mathrm{K}^{2} 2^{\mathrm{T}}$ and $\mathrm{K} 93$ were phosphatidylcholine, phosphatidylglycerol, diphosphatidylglycerol, phosphatidylethanolamine and two unidentified aminogroup-containing lipids that were ninhydrin-positive. Strain $\mathrm{K}^{2}{ }^{\mathrm{T}}$ and strain $\mathrm{K} 93$ had DNA G $+\mathrm{C}$ contents of $70.0 \mathrm{~mol} \%$.

Strains $\mathrm{K}^{\mathrm{T}}{ }^{\mathrm{T}}$ and $\mathrm{K} 93$ were shown to be most closely related phylogenetically to A. itersonii and A. peregrinum (Fig. 1). However, the $16 \mathrm{~S}$ rRNA gene sequence similarity values were too low $(<91.5 \%)$ to allow assignment of the two isolates to any recognized genus within the Alphaproteobacteria. In the phylogenetic tree based on $16 \mathrm{~S}$ rRNA gene sequences, it was found that $A$. itersonii and $A$. peregrinum are distantly related to the clade comprising Aquaspirillum serpens, the type species of the genus Aquaspirillum (Fig. 1). A. serpens is not only phylogenetically distantly related to strains $\mathrm{K} 92^{\mathrm{T}}$ and $\mathrm{K} 93$, but is also affiliated to the Betaproteobacteria. A. itersonii and A. peregrinum also showed low 16S rRNA gene sequence similarity values (91.0-91.2\%) with respect to each other. Accordingly, A. itersonii and A. peregrinum may have to be reclassified as members of two different novel genera rather than the genus Aquaspirillum. Strains $\mathrm{K}^{2} 2^{\mathrm{T}}$ and $\mathrm{K} 93$ are distinguishable from $A$. peregrinum, which has Q-9 as the predominant ubiquinone (Sakane \& Yokota, 1994). The fatty acid profiles of strains $\mathrm{K}^{2} 2^{\mathrm{T}}$ and $\mathrm{K} 93$ are similar to those of $A$. itersonii and A. peregrinum strains (see Supplementary Table S1 in IJSEM Online). However, strains $\mathrm{K} 92^{\mathrm{T}}$ and $\mathrm{K} 93$ show minor differences, relative to the two Aquaspirillum species, in the proportions of several unsaturated fatty acids, although these differences may result from differences in cultivation conditions (see Supplementary Table S1 in IJSEM Online). Strains $\mathrm{K} 92^{\mathrm{T}}$ and $\mathrm{K} 93$ are also distinguishable from $A$. itersonii and $A$. peregrinum through differences in several phenotypic properties, as shown in Table 1. The two strains are distinguishable from some phylogenetically related phototrophic purple non-sulfur bacteria, including the members of the genera Rhodospira, Roseospira and Rhodospirillum, by the absence of bacteriochlorophyll $a$ and by differences in the predominant isoprenoid quinone types (Pfennig et al., 1997; Imhoff et al., 1998; Guyoneaud et al., 2002). The low levels of 16S rRNA gene sequence similarity between strains $\mathrm{K} 92^{\mathrm{T}}$ and $\mathrm{K} 93$ and all other members of the family Alphaproteobacteria, together with the differential phenotypic properties, suggest that strains $\mathrm{K} 92^{\mathrm{T}}$ and $\mathrm{K} 93$ represent a novel genus and species within the Alphaproteobacteria, for which the name Caenispirillum bisanense gen. nov., sp. nov. is proposed.

\section{Description of Caenispirillum gen. nov.}

Caenispirillum (Cae.ni.spi.ril'lum. L. n. caenum sludge, mud; Gr. n. spira a spiral; N.L. dim. neut. n. spirillum a small spiral; N.L. neut. n. Caenispirillum a small spiral isolated from sludge).

Cells are Gram-negative, non-spore-forming and helical in shape. The predominant ubiquinone is Q-10. The major fatty acid is $\mathrm{C}_{18: 1} \omega 7 \mathrm{c}$. The major polar lipids are phosphatidylcholine, phosphatidylglycerol, diphosphatidylglycerol, phosphatidylethanolamine and two unidentified amino-group-containing lipids that are ninhydrin-positive. The DNA G + C content is $70.0 \mathrm{~mol} \%$. The type species is Caenispirillum bisanense.

\section{Description of Caenispirillum bisanense sp. nov.}

Caenispirillum bisanense (bi.san.en'se. N.L. neut. adj. bisanense of Bisan, Daegu, Korea, from where the type strain was isolated). 


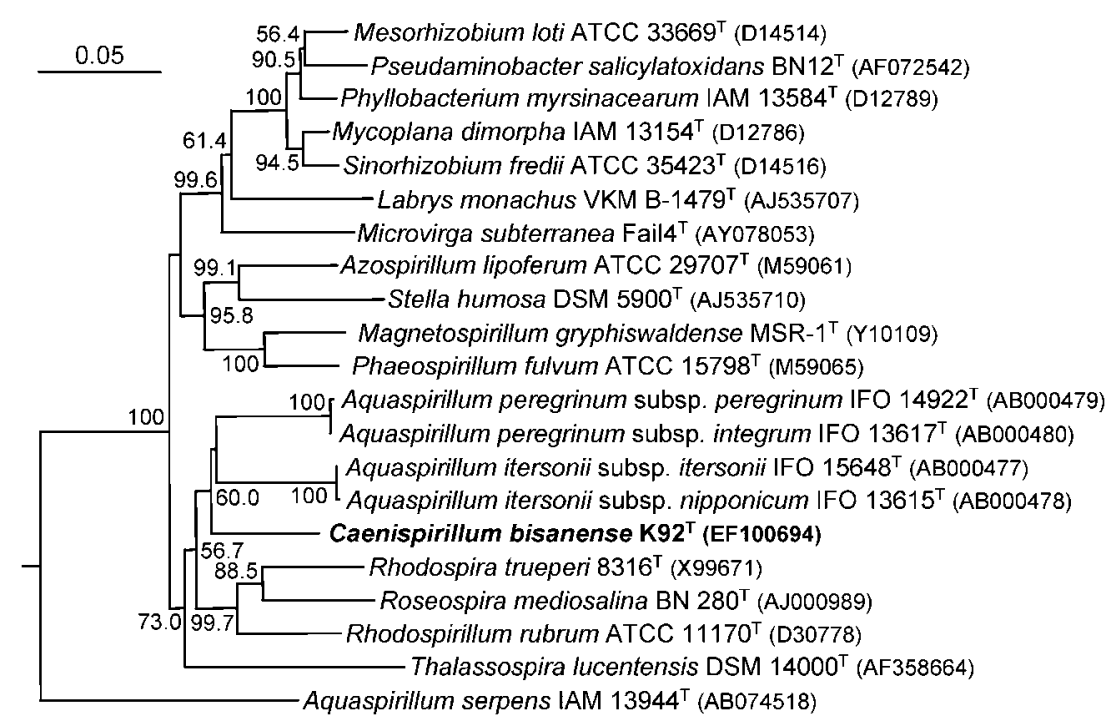

Fig. 1. Neighbour-joining phylogenetic tree, based on 16S rRNA gene sequences, showing the positions of strain $\mathrm{K} 92^{\top}$ and representatives of some related taxa. Bootstrap percentages (based on 1000 replications) greater than $50 \%$ are shown at branch points. E. coli ATCC $11775^{\top}$ was used as an outgroup (not shown). Bar, 0.05 substitutions per nucleotide position.
Exhibits the following properties in addition to those given in the genus description. Cells are 0.5-0.7 $\times 0.7-7.0 \mu \mathrm{m}$. Motile by means of a single polar flagellum. Colonies on TSA are circular, raised, smooth, glistening, greyish-yellow in colour and $1.5-2.5 \mathrm{~mm}$ in diameter after incubation for 2 days at $37^{\circ} \mathrm{C}$. Growth occurs at 15 and $47^{\circ} \mathrm{C}$, the optimum temperature being $37^{\circ} \mathrm{C}$; growth does not occur at 10 or $48^{\circ} \mathrm{C}$. Growth is observed at $\mathrm{pH} 6.5$ and 10.0 , but not at $\mathrm{pH} 6.0$ or 10.5; optimal growth occurs at $\mathrm{pH}$ 7.0-8.0. Optimal growth occurs in the presence of $0.5 \%(\mathrm{w} / \mathrm{v}) \mathrm{NaCl}$; growth occurs in the absence of $\mathrm{NaCl}$ and in the presence of $5 \%(\mathrm{w} / \mathrm{v}) \mathrm{NaCl}$, but not in the presence of greater than $6 \%$ $(\mathrm{w} / \mathrm{v}) \mathrm{NaCl}$. Tweens 20, 40, 60 and 80 are hydrolysed, but hypoxanthine, tyrosine and xanthine are not. Arginine dihydrolase, lysine decarboxylase, ornithine decarboxylase and tryptophan deaminase are absent. The following substrates are not utilized: caprate, phenylacetate, erythritol, D-arabinose, L-arabinose, D- and L-xylose, adonitol, methyl $\beta$-D-xyloside, galactose, glucose, mannose, sorbose, rhamnose, dulcitol, inositol, mannitol, sorbitol, methyl $\alpha$-Dmannoside, methyl $\alpha$-D-glucoside, $N$-acetylglucosamine, amygdalin, arbutin, salicin, cellobiose, maltose, lactose, melibiose, sucrose, trehalose, inulin, melezitose, raffinose, starch, glycogen, xylitol, gentiobiose, D-turanose, D-lyxose, D-tagatose, D- and L-fucose, D- and L-arabitol, 2-ketogluconate and 5-ketogluconate. Susceptible to ampicillin, carbenicillin, cephalothin, chloramphenicol, gentamicin, kanamycin, neomycin, novobiocin, penicillin G, streptomycin and tetracycline, but not to lincomycin or oleandomycin. Susceptibility to polymyxin B is variable (positive for type strain). In assays with the API ZYM system, alkaline phosphatase, esterase (C4) and esterase lipase (C8) are present and naphthol-AS-BI-phosphohydrolase is weakly present, but lipase (C14), leucine arylamidase, valine arylamidase, cystine arylamidase, trypsin, $\alpha$-chymotrypsin, acid phosphatase, $\alpha$-galactosidase, $\beta$-galactosidase, $\beta$-glucuronidase, $\alpha$-glucosidase, $\beta$-glucosidase, $N$-acetyl- $\beta$-glucosaminidase, $\alpha$-mannosidase and $\alpha$-fucosidase are absent.
The predominant ubiquinone is Q-10. The major fatty acid is $\mathrm{C}_{18: 1} \omega 7 c$. The major polar lipids are phosphatidylcholine, phosphatidylglycerol, diphosphatidylglycerol, phosphatidylethanolamine and two unidentified amino-group-containing lipids that are ninhydrin-positive. The DNA G $+\mathrm{C}$ content is $70.0 \mathrm{~mol} \%$. Other phenotypic characteristics are shown in Table 1.

The type strain, $\mathrm{K}^{\mathrm{T}}{ }^{\mathrm{T}}\left(=\mathrm{KCTC} 12839^{\mathrm{T}}=\mathrm{JCM} 14346^{\mathrm{T}}\right)$, was isolated from sludge from the wastewater treatment plant of a dye works at Daegu, Korea.

\section{Acknowledgements}

This work was supported by the 21C Frontier Program of Microbial Genomics and Applications (grant MG02-0401-001-1-0-0) from the Ministry of Science and Technology (MOST) of the Republic of Korea.

\section{References}

Cowan, S. T. \& Steel, K. J. (1965). Manual for the Identification of Medical Bacteria. London: Cambridge University Press.

Ezaki, T., Hashimoto, Y. \& Yabuuchi, E. (1989). Fluorometric deoxyribonucleic acid-deoxyribonucleic acid hybridization in microdilution wells as an alternative to membrane filter hybridization in which radioisotopes are used to determine genetic relatedness among bacterial strains. Int J Syst Bacteriol 39, 224-229.

Guyoneaud, R., Mouné, S., Eatock, C., Bothorel, V., Hirschler-Réa, A., Willison, J., Duran, R., Liesack, W., Herbert, R. \& other authors (2002). Characterization of three spiral-shaped purple nonsulfur bacteria isolated from coastal lagoon sediments, saline sulfur springs, and microbial mats: emended description of the genus Roseospira and description of Roseospira marina sp. nov., Roseospira navarrensis sp. nov., and Roseospira thiosulfatophila sp. nov. Arch Microbiol 178, 315-324.

Imhoff, J. F., Petri, R. \& Süling, J. (1998). Reclassification of species of the spiral-shaped phototrophic purple non-sulfur bacteria of the $\alpha$-Proteobacteria: description of the new genera Phaeospirillum gen. nov., Rhodovibrio gen. nov., Rhodothalassium gen. nov. and Roseospira gen. nov. as well as transfer of Rhodospirillum fulvum 
to Phaeospirillum fulvum comb. nov., of Rhodospirillum molischianum to Phaeospirillum molischianum comb. nov., of Rhodospirillum salinarum to Rhodovibrio salinarum comb. nov., of Rhodospirillum sodomense to Rhodovibrio sodomensis comb. nov., of Rhodospirillum salexigens to Rhodothalassium salexigens comb. nov. and of Rhodospirillum mediosalinum to Roseospira medisalina comb. nov. Int J Syst Bacteriol 48, 793-798.

Komagata, K. \& Suzuki, K. (1987). Lipid and cell-wall analysis in bacterial systematics. Methods Microbiol 19, 161-203.

Krieg, N. R. (1984). Genus Aquaspirillum Hylemon, Wells, Krieg and Jannasch 1973. In Bergey's Manual of Systematic Bacteriology, vol. 1, pp. 72-90. Edited by N. R. Krieg \& J. G. Holt. Baltimore: Williams \& Wilkins.

Lanyi, B. (1987). Classical and rapid identification methods for medically important bacteria. Methods Microbiol 19, 1-67.

Minnikin, D. E., O’Donnell, A. G., Goodfellow, M., Alderson, G., Athalye, M., Schaal, A. \& Parlett, J. H. (1984). An integrated procedure for the extraction of bacterial isoprenoid quinones and polar lipids. J Microbiol Methods 2, 233-241.

Pfennig, N., Lünsdorf, H., Suling, J. \& Imhoff, J. F. (1997). Rhodospira trueperi gen. nov., spec. nov., a new phototrophic Proteobacterium of the alpha group. Arch Microbiol 168, 39-45.

Sakane, T. \& Yokota, A. (1994). Chemotaxonomic investigation of heterotrophic, aerobic and microaerophilic spirilla, the genera Aquaspirillum, Magnetospirillum and Oceanospirillum. Syst Appl Microbiol 17, 128-134.
Sasser, M. (1990). Identification of bacteria by gas chromatography of cellular fatty acids. Technical Note 101. Newark, DE: MIDI Inc.

Tamaoka, J. \& Komagata, K. (1984). Determination of DNA base composition by reversed-phase high-performance liquid chromatography. FEMS Microbiol Lett 25, 125-128.

Wayne, L. G., Brenner, D. J., Colwell, R. R., Grimont, P. A. D., Kandler, O., Krichevsky, M. I., Moore, L. H., Moore, W. E. C., Murray, R. G. E. \& other authors (1987). International Committee on Systematic Bacteriology. Report of the ad hoc committee on reconciliation of approaches to bacterial systematics. Int J Syst Bacteriol 37, 463-464.

Yoon, J.-H., Kim, H., Kim, S.-B., Kim, H.-J., Kim, W. Y., Lee, S. T., Goodfellow, M. \& Park, Y.-H. (1996). Identification of Saccharomonospora strains by the use of genomic DNA fragments and rRNA gene probes. Int J Syst Bacteriol 46, 502-505.

Yoon, J.-H., Lee, S. T. \& Park, Y.-H. (1998). Inter- and intraspecific phylogenetic analysis of the genus Nocardioides and related taxa based on 16S rRNA gene sequences. Int J Syst Bacteriol 48, 187-194.

Yoon, J.-H., Kang, K. H. \& Park, Y.-H. (2003). Psychrobacter jeotgali sp. nov., isolated from jeotgal, a traditional Korean fermented seafood. Int J Syst Evol Microbiol 53, 449-454.

Yurkov, V., Stackebrandt, E., Holmes, A., Fuerst, J. A., Hugenholtz, P., Golecki, J., Gad'on, N., Gorlenko, V. M., Kompantseva, E. I. \& Drews, G. (1994). Phylogenetic positions of novel aerobic, bacteriochlorophyll a-containing bacteria and description of Roseococcus thiosulfatophilus gen. nov., sp. nov., Erythromicrobium ramosum gen. nov., sp. nov., and Erythrobacter litoralis sp. nov. Int J Syst Bacteriol 44, $427-434$. 